\title{
sciendo
}

DOI 10.2478/sbe-2018-0020

SBE no. 13(2) 2018

\section{DOES REIT OFFER A BETTER RISK AND RETURN CONTOUR TO THE NEW ZEALAND RESIDENTIAL PROPERTY INVESTORS?}

\author{
CHONG Fennee \\ Auckland University of Technology, New Zealand
}

\begin{abstract}
:
New Zealanders' overwhelming favour of residential property investment has resulted in residential properties being overvalued with a house-price-to-income multiple equals to 5.9 for the country and 10 for its largest city - Auckland. With the deterioration in housing affordability; currently ranked the fourth worst in the world for Auckland (the largest city in New Zealand), investing directly in residential property become riskier. Under this scenario, a more passive property investment option such as REIT could be more viable. The objective of the paper is to assess whether REIT could offer a better risk and return contour then direct residential property option to potential property investors in New Zealand. Empirical findings from this study show that there is a significant difference between the rates of return of these two types of property investment options. Further analysis using Treynor ratio indicates that investing in REITS generated a higher return on a risk-adjusted basis. This finding has implications for investors looking for a more affordable and liquid way to tap into the property asset class.
\end{abstract}

Key words: Residential Property Investment, Real Estate Investment Trust

\section{Introduction}

According to Cheung (2011) the most popular type of property investment in New Zealand is the residential property investment. Investors prefer this property investment option because i) it is a tangible form of investment, ii) direct ownership allows investors to have total control on the investment, iii) residential property is highly in demand as home ownership is one of the most important aspects in one's personal financial planning, iv) returns comprise both capital gain and rental income and v) it is a relatively stable form of investment as land is scarce. Nevertheless, it is also the most capital intensive among all the asset classes and the costs involved include brokerage for agents, solicitor fees, interest expenses, valuation fees and council fees.

However, it is not necessary for property investors to buy a house and rent it out for return in the property market. Real estate investment trust (REIT) is another 
option to invest in the property market. A REIT is a type of security that invests in real estate market and is often traded like a stock on major exchanges. In comparison with the direct residential property investment option, REIT has the advantages of lower entry barrier, higher liquidity as it can be easily sold in the open market should the property market goes down, and is professionally managed. Despite these advantages, REIT remains thinly traded in New Zealand. In view of the fact that $61 \%$ of New Zealander's financial knowledge was rated between low to medium in the survey carried out by the Commission for Financial Literacy and Retirement Income (2013), a plausible reason for the limited interest in REIT is the lack of study and awareness on what REIT can offer as an alternative instrument to enter the property market. So far, no comparative study on property investment options has been done in New Zealand. To fulfil this gap, this study aims to investigate whether REIT provides a better risk and return contour than direct investment into the residential housing market to potential investors.

\section{Literature Review}

Investment in residential property is different from home ownership as the ultimate aim of the residential property investment is for future cash flow in the form of rental income, and capital gain when the property is put up for sale in the market place rather than for shelter and psychological reward as a homeowner. Buying a property obviously requires more careful planning and analysis as it involves larger capital outlay and is relatively illiquid in comparison with asset classes such as REITs, stocks and bonds. Apart from deciding on the location and the size of property, factors such as the availability of mortgage, interest rates, down payment, insurance, management and maintenance fees, as well as tax planning, need to be taken into consideration as well (Kapoor, Dlabay \& Huges, 2013).

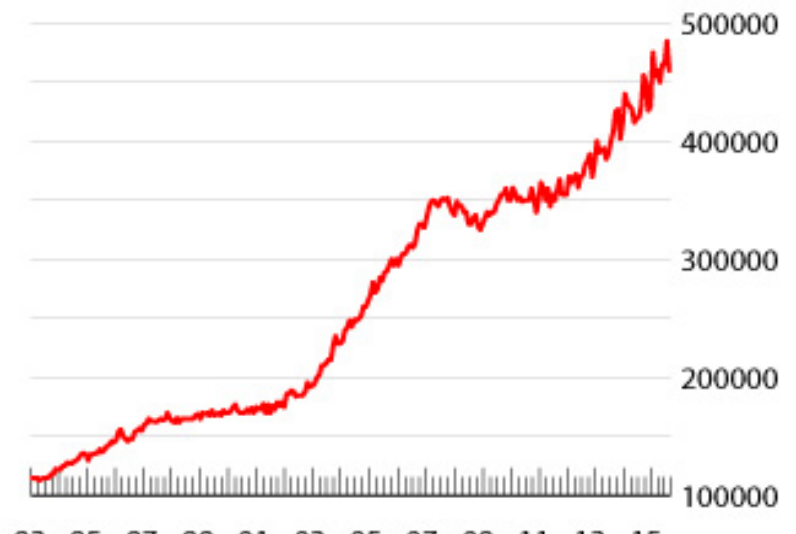

$\begin{array}{llllllllllll}93 & 95 & 97 & 99 & 01 & 03 & 05 & 07 & 09 & 11 & 13 & 15\end{array}$

Figure 1: Median house price (in NZ\$)

Source: globalpropertyguide.com 
From the graph above, the median residential price in New Zealand has reported an upward growing trend after the global financial crisis in 2008. In fact, New Zealand housing was among the top five least affordable in the world (OECD, 2015). Among the twelve regions in the country, Auckland reported the biggest house price rise followed by central Otago and Wellington after the subprime crisis. As at September 2015, owner occupied houses account for $63.7 \%$ of private dwellings, $32.6 \%$ were investment property (Global property guide, 2015).

Broome (2008) contends that the residential capitalism in New Zealand was driven by the neoliberalism and financial change took place in the country in the 80s and 90s. Among others, the liberalization of the foreign exchange, banking sector and the removal of restriction of foreign borrowing by domestic financial institutions have shifted the notion of housing as a social right to residential capitalism. These reforms coupled with the absence of capital gain tax for decades have endowed investors the rights to take advantage of the situation by commodifying residential housing and treat this investment as a safe heaven for wealth accumulation and future financial security. Upper income household are benefited the most as they were able to gain access to mortgage to invest in multiple residential properties under a more liberalized lending system. This tendency would eventually bring about a housing bubble policy nexus that inhibits the functionality of the country's macroeconomic framework. In fact, recent reporting on the growing numbers of working families being forced to live in vehicles due to being unable to afford the soring rent and buying a simple shelter have generated concerns in the media (Wesley-Smith, 2016).

An earlier research conducted by De Bruin and Flint-Hartle (2003) on the New Zealander's property investment behavior using the bounded rationality framework found that wealth accumulation and long-term capital gain was the main motivation to invest in residential property. Capital gain tax on housing in New Zealand was slack and only introduced in 2015 for residential property sold within two years after the purchase. This partly has contributed to the comment indicates it is possible to "get rich because tenants pay the mortgage" in De Bruin and Flint-Hartle (2003) survey. The research also highlighted that only one in thirty-five interviewees calculated the returns, others mostly invest based on their "gut feeling" that they were getting a good return. Herding biases seems to be able to move the market towards the "believed direction".

Braithwaite and Kemp (2007) surveyed the risk appetite of residential property investors in New Zealand using the Investment Risk Attitude Scale. They invited participants to rate their confidence in investing in financial instruments such as term deposits, unit trust, shares, residential property or a residential property syndicate. Results show that New Zealanders are more confident about investing in residential property than any other option. These investors also label themselves as a non-risk seeker and feel that residential property investment suit their risk appetite. Participants generally are lack of interest in other form of investment other than residential housing.

Due to the investment attitude discussed earlier, even though REITs are listed on the NZX50, they are thinly traded and did not generate much research interest. On the other hand, New Zealand's close neighbour, Australia has a much well-developed 
REIT market. According to Yong and Singh (2015), Australian REITs outperformed equities investments in Australian for the past two decades. Nonetheless, despite REITs' attractiveness in terms of higher dividend pay-outs, being perceived as having a lower risk than equity investments, REITs performance can be influenced by macroeconomic factors and economic trends. Furthermore, REITs with higher debt levels are more sensitive to interest rate risk and downward market conditions.

A related study by Ooi, Newell and Sing (2006) examines the growth of REIT markets in Asia. They contend most of the investors seem to be having problem differentiating REIT against the more well established property stocks listed on the major stock exchanges in Asia. As a matter of fact, REIT is different from property stock in terms of: i) business focus ii) dividend policy iii) custody of properties as well as iv) investment and leverage guidelines. In relation to business focus, as REIT is associated to a specific sector of real estate, they tend to act as a low-risk investment alternative to property stocks. REITs in Japan, Singapore and South Korea managed to produce an annualised return of $32.5 \%, 38.5 \%$ and $5.6 \%$ respectively as at the end of 2005 (Ooi et.al., \& Sing, 2006, \& Moneysense, 2016).

Raudszus, Olloges and Mueller (2012) study whether REITs behave more like common equities or direct property investment when the price of liquidity are high. They contend that retail, residential and healthcare REITs produce positive abnormal returns relative to common equities. They also posit that equity-REITs and propertyREITs carry the least risk during economic downturn comparing to mortgage REITs. Ghosh, Miles and Sirmans (1996) on the other hand argue that REITs are affected by the volatility in the stock market in the short-run but their long-run returns are closely linked to real estate growth.

In the US context, Hardin, Hill and Hopper (2009) investigate the impact of ownership and management structure of lodging properties such as motels and hotels' performance. Their findings show that multifamily lodging properties owned and managed by REITs perform better than non-REIT- owned properties. The authors also highlight the fact that professionally managed REIT lodging properties have the advantage of cost-related scale economies and a better access to the rental market and submarket have resulted in better performance.

\section{Data and Methodology}

The sample period of monthly data for this study covers January 2009 to January 2016. The data of average monthly residential property value per unit in New Zealand is collected from the database of Quotable Value Ltd (QV), a State Owned Enterprise and the largest property valuation company in New Zealand. Monthly average REITs price data over the same period are collected from the New Zealand Stock Exchange (NZX) for analysis. 
Asset performance is measured with regards to its risk and return (Bodie, Kane \& Marcus, 2014). To provide some indications on the return of REITs and residential property investment options, the average yearly return of listed REITs on the NZX and residential property for New Zealand are calculated.

Nonetheless, analysis of different investment options would not be complete if risk assumed is not included in the analysis. Therefore, Treynor ratio is used to analyse the risk adjusted returns of the invest options included in this study. Treynor ratio examines how well an investment performed against the market i.e. this ratio recognises the presence of systematic risk. Treynor ratio is useful in this context as it measures the risk-reward trade-off of an investment given its level of risk. It can be calculated using the following formula:

Trejnar Ratio $=\frac{A_{p}-R_{52}}{\beta}$

Where:

$R_{\mathrm{p}}=$ Expected asset return

$R_{r f}=$ Risk-free rate of return

$\beta=$ Market risk

To generate empirical findings on whether the returns of residential properties and REITs are significantly different, a test of equality was performed to answer the following hypotheses:

$H_{0}$ : There is no significant difference between the performance of residential property investment and REIT investment in NZ.

Descriptive statistics, results of Treynor ratio analysis and test of equality will be discussed in the next section.

\section{Analysis and Results}

\subsection{Descriptive statistics}

Table 1: Returns of residential housing and REIT investment

\begin{tabular}{lc}
\hline Variable & $\%$ \\
\hline Average capital gain per year before adjustment & 7.79 \\
Average return (capital gain and rental yield) before adjustment & 12.21 \\
& 0.98 \\
Yearly return after adjustments Note 1 & 13.04 \\
\hline
\end{tabular}

Note 1:

- After interest, sales commission, property management fees and rental yield. Capital gain tax rate is determined by the investor's tax bracket, therefore, it is not taken into consideration. Rental yield was calculated using the bond submission data obtained from Ministry of Business, Innovation and Employment New Zealand. 
Table 1 reports the returns of residential housing property under study. The yearly average return of New Zealand residential property during the study period was $7.79 \%$ before adjustments. This return drops to $0.98 \%$ per annum after adjusting for interest payment, rental yield, sales and property management fees. On the other hand, investors can fetch a $12.21 \%$ return if they purchase the residential property using cash and rent the property out without using a property management agent. On the other hand, REITs reported an average return of $13.04 \%$ per annum during the study period. Commission for REIT transactions is $0.3 \%$ per trade using the internet, $0.7 \%$ via telephone and $1 \%$ for sale through a broker.

Based on the descriptive statistics discussed above, REITs have offered a higher return then residential property investments during the study period. However, comparing to those of Japan and Singapore, there is still room for further improvement for New Zealand REITs (Ooi et.al., 2006).

\subsection{Test of Equality}

Table 2: Equality of means between series test

\begin{tabular}{lll}
\hline Variables & Wilcoxon/Mann- & Probability \\
& Whitney statistics & \\
\hline Return of residential property NZ versus REIT return & 3.128 & 0.0018 \\
\hline
\end{tabular}

To confirm on whether REIT investment return is significantly better than residential property investment statistically, a test on mean equality was conducted based on the hypotheses stated earlier. Finding in Table 2 shows that there is a significant difference between the adjusted returns of New Zealand residential property and REIT investments at a 95 percent confidence level. This result supports that of Hardin, Hill and Hopper (2009). REITs tend to perform better than property managed by private owners because they are managed by professionals with better property management skills. Furthermore, REITs also have the advantages of cost-scale efficiency and revenue enhancement due to better market access.

\subsection{Risk Assessment}

Table 3: Risk assessment using Treynor Ratio

\begin{tabular}{lc}
\hline Variables & Treynor Ratio \\
\hline Return of NZ residential property & 2.74 \\
\hline Return of REITs & 9.05 \\
\hline
\end{tabular}

The Treynor ratio measures returns earned in excess of a risk free asset per each unit of market risk. It is often used to rank and compare investments within the same sector where a higher Treynor ratio is preferred (Ross, Westerfield \& Jordan, 2007). Results in Table 3 show that investing in REITs generated a higher return on a risk-adjusted basis at $9.05 \%$ per unit of systematic risk; $6.31 \%$ better than residential 
property investment. A possible reason for REIT's better reward-to- market volatility was REIT is more diversified and was managed by professional fund managers.

\section{Conclusion}

From the analyses discussed above, REIT outperformed residential property investment in New Zealand during the study period. Empirical test result indicates that the difference between the returns of these two property investment options is significant at $95 \%$ confidence level. Risk assessment using the Treynor ratio indicates that REIT top the chart on a risk adjusted basis indicating REIT has a higher rewardto-volatility ratio. Based on the empirical results, the advantages that REIT could offer, and the worsening affordability of the residential market, investors could consider REIT as an option when entering New Zealand's property market. Future research could extend this study with additional time periods and include others investment options to advance more insights on the investment options in New Zealand.

\section{References}

Bodie, Z., Kane, A., \& Marcus, A. J. (2014): Investments (10 ${ }^{\text {th }}$ ed.), McGraw-Hill Education, New York.

Braithwaite, F. D. \& Kemp, S. (2007), Safe as houses: Investor confidence in New Zealand. New Zealand Economic Papers, Vol. 41, no. 2, pp. 225-236.

Broome, A. (2008), Neoliberalism and financial change. The evolution of residential capitalism in New Zealand, Comparative European Politics, Vol. 6, no. 3, 346-364

Cheung, C. (2011), Policies to rebalance housing markets in New Zealand. OECD Economics Department Working Papers, 878, July, available online at http://www.oecdilibrary.org/economics/policies-to-rebalance-housing-markets-in-new-zealand

De Bruin, A. and Flint-Hartle, S. (2003), A bounded rationality framework for property investment behaviour, Journal of Property Investment and Finance. Vol. 21, no. 3, pp.271-284.

Demographia (2017), 13th Annual Demographia International Housing Affordability Survey: 2017 Rating Middle-Income Housing Affordability, available online at www.demographia. com/ dhi-pdf.

Commission for Financial Literacy and Retirement Income (2013), Financial Knowledge and Behaviour Survey, available online at http://www.cffc.org.nz/assets/Documents/FKBS2013-June-Financial-Knowledge-and-Behaviour-Survey-Summary.pdf

Ghosh, C., Miles, M., \& Sirmans, C.F. (1996), Are REITs stocks? Real Estate Finance, Vol.13, pp. 46-53.

Global Property Guide (2016), The New Zealand puzzle: Low population, high property prices (and high rents), available online at http://www.globalpropertyguide.com/Pacific/NewZea/Price-History-Archive/ArchiveThe-New-Zealand-puzzle-low-population-high-propertyprices-and-high-rents-127403

Hardin, W. G., Hill, M. D., \& Hopper, J. J. (2009), Ownership structure, property performance, multifamily properties and REITs, Journal of Real Estate Research, Vol. 3, no.31, pp. 285-306. 
Kapoor, J.R., Dlabay, L.R., \& Huges, R.J. (2013), Focus on personal finance (4 ${ }^{\text {th }}$ ed.), McGrawHill Irwin, New York.

MoneySense (2016), Real estate investment trusts, available online at http://www.moneysense.gov.sg/Understanding-Financial-Products/Investments/Types-ofInvestments/Real-Estate-Investment-Trusts.aspx.

OECD (2015), Economic Survey of New Zealand 2015 available online at http://www.oecd.org/newzealand/economic-survey-new-zealand.htm

Ooi, J.T.L, Newell, G., \& Sing, T. (2006), The growth of REIT markets in Asia, Journal of Real Estate Literature. Vol. 14, no. 2, pp 203-222.

Quotable Value Limited (2016), Residential house values. available online at https://www.qv.co.nz/resources/monthly-residential-value-index.

Raudszus, M.H., Olloges, J., \& Mueller, G. R. (2012), Bank failures and REIT returns, Journal of Real Estate Portfolio Management. Vol. 18, no.1, pp. 1-22.

Ross, S., Westerfield, R.W., \& Jordan, B.D. (2007), Corporate Finance Essentials (5 $5^{\text {th }}$ ed.), McGraw-Hill Irwin, Boston.

Yong, J., \& Singh, A. (2015), Interest rate risk of Australian REITS: A panel analysis, Pacific Rim Property Research Journal, Vol. 21, no.1, pp. 77-88.

Wesley-Smith, M. (2016), The hidden homeless: Families forced to live in cars, May, available online at www.newshub.co.nz/nznews/the-hidden-homeless-families-forced-to-live-incars-2016051314. 